\title{
Compliance of Companies With Corporate Governance Codes: Case Study on Listed Belgian SMEs
}

\author{
Sven H. De Cleyn \\ University of Antwerp, Belgium
}

\begin{abstract}
Listed and large companies become increasingly subject to internal and external pressure to comply with ethical and social standards. This article focuses on one aspect of this matter, namely the corporate governance issue. Within the framework of recent corporate scandals, this paper investigates whether and to which extent Belgian publicly listed SMEs comply with the Belgian Code on Corporate Governance after its first year of introduction, which has been constituted in the framework of the European Action Plan on Corporate Governance.
\end{abstract}

In a sample of 78 Belgian listed SMEs, the compliance with the Code is analysed. After its first year of introduction, companies comply with on average $70 \%$ of the Code's provisions. The most problematic topics in terms of disclosure of information seem to relate to (individual) remuneration, private information and content of shareholders' meetings.

\section{Keywords}

Corporate Governance; European Action Plan; Belgium; Code Lippens; Code on Corporate Governance

\section{Introduction}

Listed companies become increasingly subject to internal and external pressure to comply with ethical and social standards (Levis, 2006). This article focuses on one aspect of this matter, namely the corporate governance issue. The attention paid on the corporate governance issue has been growing unremittingly, especially since some large corporate failures due to fraud and manipulation in the nineties (Becht et al., 2005; Coffee, 2005; Commission of the European Communities, 2003; Marnet, 2007). In recent years, many countries engage in debates on the implementation and enforcement of a corporate governance code or law for companies. In 2003, the European Commission formulated an action plan on corporate governance, intending to enhance transparency and the disclosure of information (Berglöf 1997; Berglöf and Pajuste, 2005). Indeed, information disclosure is seen as a pillar in the move towards better governance of European companies (Dalton and Dalton, 2006a). The ultimate goal of the EU is to foster the global efficiency and competitiveness in EU companies and safeguard the position of shareholders and all stakeholders involved (Commission of the European Communities, 2003), where a corporate governance code serves as one tool amongst many other to reach this objective. Amongst many other countries, Belgium has started initiatives to comply with this

Copyright (C) 2008 Victoria University. This document has been published as part of the Journal of Business Systems, Governance and Ethics in both online and print formats. Educational and non-profit institutions are granted a nonexclusive licence to utilise this document in whole or in part for personal or classroom use without fee, provided that correct attribution and citation are made and this copyright statement is reproduced. Any other usage is prohibited without the express permission of the call.

Within this framework, this paper investigates whether and to which extent the Belgian publicly listed Small and Mediumsized Enterprises (SMEs) comply with the Belgian Code on Corporate Governance (further referred to as the "Code") after its first year of introduction, better known as 
the Code Lippens (named after the chairman of the committee). Generally, the Belgian corporate governance model is based on the stakeholder approach (Wieland, 2005), as opposed to the shareholder model, common in countries such as Switzerland, Sweden, Finland and the UK (Wieland, 2005). The analysis is based on the annual reports, the companies' website and the Corporate Governance Charters. The purpose of the paper is then to unveil to which extent the companies comply with the code and the main reasons for non-compliance.

The remainder of the paper is structured as follows. The second section deals with general aspects of the corporate governance theory and practice. The literature elements most relevant to this paper are discussed in more detail. In the third section, the Belgian corporate governance situation is touched upon. A rather recent development is of major importance in this research field, namely the (separate) creation of a corporate governance code for listed (the "Code Lippens") and non-listed Belgian companies (the "Code Buysse"). In the same section, the research focus of this paper is specified. The fourth section deals with methodological issues and description of the research sample. A case study approach on the Belgian situation has been chosen. The presentation and discussion of the findings occurs in the fifth section. Special attention is drawn on provisions of the corporate governance code with which the companies comply least. A final discussion on the implication of the findings and the limitations of the study ties up this paper.

\section{Corporate Governance}

\section{General framework}

The competitive environment in which companies operate has changed at fast pace in recent decades (Revilla et al., 2005; Trott, 1998; Vuola and Hameri, 2006). The development of effective and efficient control systems is then required if companies wish to seize these opportunities and stand up to the accompanying risks. A corporate governance system forms an important part of this control system. In the light of this context - and as a result of the recent corporate scandals, mainly in the United States many countries and international communities (e.g. the OECD) have been developing regulations and guidelines on required levels of corporate governance (Berglöf, 1997; Gillan, 2006; Marnet, 2007).

In the light of the recent corporate scandals, the existing systems proved not to be satisfactory and could easily be undermined (Marnet, 2007). In the United States the Sarbanes-Oxley Act provided a quick reaction to the scandals. Poor governance by some companies has, according to the European Commission - "greatly undermined confidence in capital markets" (Commission of the European Communities, 2003, p. 10) and has fostered the need a European tackling of the issue. Shareholders and stakeholders proved not to be protected sufficiently. Therefore, the EU decided to put effort into the subject at a supranational level. According to Becht et al. (2005), two alternative responses are possible: stricter standards and more tight regulation on the one side or more optimal functioning of markets through better information disclosure - on the other side. These approaches do not need to be mutually exclusive - an opinion which is reflected by the particular elaboration of the EU call in Belgium. However, in most cases, changes in legislation is the easiest response to corporate scandals (Marnet, 2007), leaving companies and courts struggling with the new rules (Berglöf and Pajuste, 2005). The European Union has mainly chosen the path of issuing guidelines and creating a reference framework through the European Action Plan of May 2003 - instead of imposing a new legislative regime. This plan delegates the constitution of a corporate governance code to the individual member states, as after careful analysis of advantages and obstacles - it is estimated not interesting to formulate a single corporate governance code for the European Union (Commission of the European Communities, 2003). The code should be applicable to all listed European companies and the main goal is disclosure of relevant and important company information, as stimulus for having well-functioning markets (Berglöf 1997; Berglöf and Pajuste, 2005; Claessens and Fan, 2002). An important aspect of the intended codes is the 'comply or explain' principle. According to this principle, companies not complying with one or 
more provisions of the code should explain their reasons for deviation (this subject will be dealt with in more detail in the next section).

The Action Plan then seeks to enhance the general framework on several domains. Information disclosure is a key pillar for achieving these goals (Basu et al., 2007; Berglöf and Pajuste, 2005; Claessens and Fan, 2002). Secondly, as the corporate scandals illustrate, shareholders' rights should be strengthened, especially through - again - substantial and adequate information disclosure and increased shareholder democracy and activism (Commission of the European Communities, 2003; Daily et al., 2003). Additionally, an important role is in store for the Board of Directors. Through its composition (strengthening the role of especially independent and non-executive directors), remuneration and responsibilities, the governance of a company can strongly be enhanced (Dalton and Dalton, 2006a; Giannini, 2001; Hendry, 2005; Siebens, 2002).

The European Commission intends to achieve two main objectives with the Action Plan (Commission of the European Communities, 2003). In the first place, the intention is to strengthen shareholders' rights and third party protection in the competitive environment. Secondly, the policy objective is to foster business effectiveness and competitiveness (Commission of the European Communities, 2003; Wymeersch, 2006).

Many European countries have opted not to wait for or respond to Community initiatives but have already compiled up-to-date regulations or guidelines on corporate governance. As first European countries, France, the UK and the Netherlands have published their respective codes on corporate governance in 2003. Belgium built upon separate draft versions of 1998 of three instances and published an integrated code on corporate governance in 2004 (see further on for more details). As the Commission of the European Communities takes part in the work of the OECD, the EU initiatives relates strongly to the OECD guidelines on corporate governance.

\section{Some theoretical considerations}

Many scholars have investigated different aspects of corporate governance. The main theoretical stream influencing actual body of thought on corporate governance is the agency theory. The ongoing discordant field of tension and conflicting interests of a company's owners and managers as a result of the separation of ownership and control - as often a company's ownership and control are separated through these parties - leads to a potential governance problem (Frey and Benz, 2005; Hendry, 2005; Shleifer and Vishny, 1997; Wieland, 2005). The central legislative solution to solve the agency problem is the monitoring role of the Board of Directors (Hendry, 2005). Therefore, many scholars and corporate governance codes stress the important role of the Board. According to Van den Berghe and Baelden (2005, p. 680), there is indeed a strong attention in both literature and practice (especially in corporate governance codes) on this monitoring role, offering a solution and mechanism to align the interest of shareholders and managers and thereby reducing or solving the agency problem at least partially (Hendry, 2005).

As corporate governance is currently gaining more and more research attention (Claessens and Fan, 2002), different perspectives and definitions appear, depending on one's view of the world. Shleifer and Vishny (1997) proposed a rather narrow, shareholder-oriented definition. They define (p.737) corporate governance as "Corporate governance deals with ways in which suppliers of finance to corporations assure themselves of getting return on their investment". This reflects the more Anglo-American view on companies, where investments and ownership have to be protected and shareholder value is the cornerstone of the corporate governance system (Shleifer and Vishny, 1997; Wieland, 2005; Aaboen et al., 2006), whereas other goals have to be served (e.g. job security) according to for example Japanese firms (Becht et al., 2005). To reflect this wider view on corporate governance, Gillan and Starks (1998) presented a broader definition. They defined corporate governance as "the system of laws, rules, and factors that control operations at a company". The European Commission employs a similar definition: "Corporate governance is the system by which companies are directed and controlled" (Commission of the European Communities, 2003, p. 10). These definitions reflect the broader view, involving all 
stakeholders of a company instead of focussing exclusively on shareholder value (Wieland, 2005; Wymeersch, 2006). However, these definitions refrain from stressing the accountability aspect, which corporate governance makes for. The corporate governance framework indeed emphasizes a company's responsibility towards all stakeholders.

In both perspectives, internal and external mechanisms have impact on the organisation. In a recent work, Gillan (2006) provided an overview of the latest developments in the corporate governance field. Thereby, he developed a framework over the borders of different perspectives on this issue, adopting a broad view on corporate governance (see Figure 1). The company is then seen as a nexus of contracts between individuals and groups, both internal and external, cooperating with the company (Jensen and Meckling, 1976; Ooghe et al., 2002).

Figure 1: View on corporate governance.

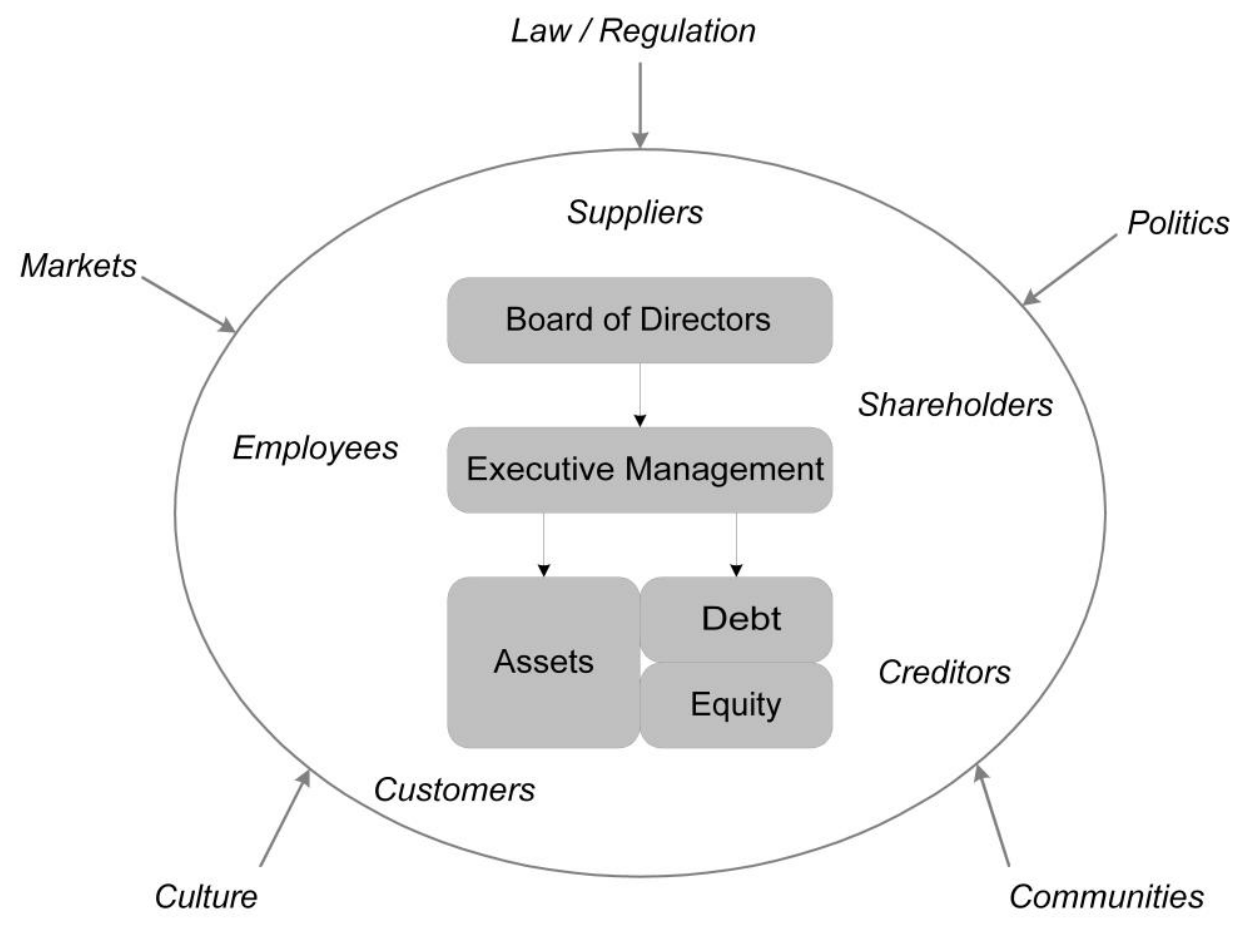

Source: Gillan, S. L., 2006. Recent developments in corporate governance: An overview. Journal of Corporate Finance 12, 381-402.

\section{Regulation versus self-regulation}

An ongoing debate in corporate governance matters relates to the need for regulation (a legal framework) versus self-regulation by companies (e.g. non-binding corporate governance codes). A legal framework offers clarity and uniformity across companies and industries and enhances the enforceability of good governance practices. Additionally, first studies related to the subject indicate that little outcome can be expected from initiatives that rely on self-regulation and monitoring without any legal enforcement (de Jong et al., 2004). Additionally, obligatory reporting can be argued to be a powerful incentive to achieve compliance. Alternatively, obligatory reporting is in itself not enough to guarantee compliance genuine compliance with corporate governance codes and the philosophy behind them. Several arguments plead however for self-regulation.

The external factors fostering the introduction and compliance with corporate governance codes meet two different risks: regulatory risks and social risks. The first argument is used by companies in order to reduce the need for other forms of regulation and legislation (Levis, 2006, p.51). They argue that, by 
implementing and complying with a corporate governance code, less formal legislation is needed. However, as there is no formal and external control organ to assess and enforce the compliance with the codes, its effectiveness is doubtful.

Secondly, corporate governance codes provide a response to social pressure and need for legitimation (Aguilera and Cuervo-Cazurra, 2004; Levis, 2006, p.51), meeting the demands of different stakeholders and external parties (McWilliams and Siegel, 2001). In a related manner but somewhat more specific, Wymeersch (2006) identified peer pressure as motivation for compliance and argument for selfregulation. As weak governance practices in one company may spill over to damage the reputation of other board; peer pressure can be seen a self-controlling element, thereby justifying self-regulation.

A third internal driver for managers to adopt corporate governance codes is the desire to protect both the company's and their own reputation (Levis, 2006, p.52). Wymeersch (2006, p.2) stated that corporate governance codes essentially have "moral value", which can be seen as driver for compliance, thereby reducing the need for legal regulation.

In fourth instance, capital market will assess compliance with the code and will (a) penalise noncompliance through the stock market valuation (Easterbrook and Fischel, 1996; Wymeersch, 2006) or (b) accept non-compliance in case of a justifying circumstances (Anand, 2005).

A fifth and last argument in favour of opting for self-regulation concerns flexibility. In corporate governance matters, the "one size fits all" approach is not deemed satisfactory. Companies need flexibility to adapt good governance practices to their specific situation. According to Wymeersch (2006, p. 4) codes should be an incentive to evolve towards better governance standards, without revolution in the internal structures and procedures. This dynamism and flexibility are cornerstones in the process towards better governance practices. The "comply or explain" principle (see further for a more detailed discussion) fits in this view. On the other hand, an equal countervailing argument can be put forward, as a minimal regulative framework is needed to uphold the intrinsic values behind corporate governance codes.

McWilliams and Siegel (2001) argued that effective corporate governance systems tend to cost companies less than they yield. This idea is very important, as the enforcement and viability of corporate governance codes relies on its costs and benefits perceived by the companies. In previous decades, the costs of compliance outweighed the benefits by multiple factors. However, as a legislative and social framework is being built up in recent years, 'irresponsible' companies incur increasingly disadvantages because of their non-compliance. The constitution of codes on corporate governance throughout Europe can therefore be seen as an important step towards a stronger corporate governance framework.

\section{"Comply or explain" principle}

Many corporate governance codes have been based on the "comply or explain" principle, according to which compliance with the code's provisions is not a necessity but disclosure relating to compliance is (Aguilera and Cuervo-Cazurra, 2004; MacNeil and Li, 2006). The principle has been in operation in the United Kingdom for 13 years and has been introduced in most recently adopted codes in different EU member states. Its main goal is information disclosure, which has been previously identified as cornerstone in creating a good corporate governance framework and helps to protect investors (Basu et al., 2007; Berglöf and Pajuste, 2005; Claessens and Fan, 2002; MacNeil and Li, 2006).

The reasoning behind the introduction of the "comply or explain" principle consists of two main arguments. Firstly, one might argue that a "one size fits all" approach in corporate governance matters is not practicable (MacNeil and Li, 2006; Wymeersch, 2006). Companies differ strongly in their structures, goals and subsequent corporate governance needs. Therefore, the principle brings flexibility in order to meet the company's needs and specific characteristics. The second argument relates to capital market's role in evaluating the extent to which company comply with the provisions of the code (MacNeil and Li, 2006). According to this argument, the code represents the view of institutional 
investors as to best practice, which can serve as incentive to comply, as compliance might have a positive impact on share price evolution (Mallin, 2001). Non-compliance offers then the possibility to justify a company's position towards investors (MacNeil and Li, 2006).

\section{Monitoring compliance with codes}

The disclosure obligation of corporate governance codes provides a mechanism to observe and monitor a company's compliance (MacNeil and Li, 2006; Wymeersch, 2006). However, compliance viewed apart is subjective, as not all analysts and investors will agree on this matter. Moreover, not all provisions of such codes are capable of independent verification (MacNeil and Li, 2006; Wymeersch, 2006). Additionally, a gap might exist between what companies report concerning compliance and what they actually exercise in daily business practice. The same holds for the use of the "comply or explain" principle. The explanation provided to justify non-compliance might not be true and reliable (Wymeersch, 2006).

\section{Corporate Governance in Belgium}

This section turns our minds to the Belgian corporate governance situation in general and the specific recent development in particular. The research opportunity is identified, stemming from the EU Action Plan. The opportunity identified at EU level is executed and analysed at Belgian level.

\section{Code Lippens \& Code Buysse}

In the last decade, the attention paid to corporate governance has grown substantially in Belgium especially since 1998, when 3 parties independently developed guidelines and recommendations on the subject. The three parties involved were the Banking, Finance and Insurance Commission, the Federation of Enterprises in Belgium (FEB) and Euronext Brussels. In a more recent joint effort acting upon the decision of the European Commission of $21^{\text {st }}$ May 2003 - the same three parties established the Corporate Governance Committee on $22^{\text {nd }}$ January 2004 under the chairmanship of Maurice Lippens.

The aim of the Committee is "to update these recommendations by drafting a single reference code for listed Belgian companies. The Code is to set out principles of good governance and transparency, which will contribute to the development of companies and to the quality of their image among investors and the general public." (Corporate Governance Committee, 2007). The final Belgian Corporate Governance Code has been published in December 2004. In line with European train of thought, the Belgian Corporate Governance Code (Code Lippens) encompasses guidelines for listed companies and contains no legal obligations.

Additionally, Belgium has decided to constitute a second code, intending to provide guidelines for smaller, non-listed companies. This code has also been presented at the end of 2005. This Code Buysse aims to provide helpful and practical insights for SMEs and other non-listed companies in order to fully realise the growth and innovation objectives of the company. A specific part of the Code Buysse is directed towards family-owned ventures, to address their specific problem areas and concerns.

The focus of this study will entirely remain with the Code Lippens, as adequate and substantial information is only available for listed companies. The Code Buysse therefore falls outside the scope of this study.

\section{Research opportunity}

The new Code on Corporate Governance can be considered a milestone in the corporate governance practice in Belgium and - taking the European action plan into account - in Europe. The renewed élan opens up several research opportunities for researchers, legislators and practitioners. In the first place - 
the most obvious question - one can investigate to what extent companies comply with the provisions set out in the code. The question is relevant and interesting, as the Code contains guidelines and does not hold any regulatory obligations for the companies under investigation. The answer on this question not only reveals the extent to which companies comply with imposed guidelines, it also reflects the companies' culture and real concern at corporate governance and explains different statistics and facts (Berglöf and Pajuste, 2005; Dalton and Dalton, 2006b). Therefore, the first research question can be formulated.

\section{Research Question 1}

To what extent do the listed Belgian SMEs report compliance with the Belgian corporate governance code (Code Lippens)?

The Code foresees in the possibility to explain non-compliance with provisions of the code - the "comply or explain principle". These explanations can be considered being interesting sources of information, especially because they reflect areas subject to more controversy in business practice. The non-disclosure of information can possibly be an indication of companies' reluctance on some subjects. Information disclosure is critical in ameliorating markets' functioning (Becht et al., 2005; Berglöf, 1997; Claessens and Fan, 2002). Therefore, analysing the reasons for non-compliance can reveal interesting concerns in the business world with respect to corporate governance (Berglöf and Pajuste, 2005). The second research questions can then be formulated.

\section{Research Question 2}

What are the reasons in case of non-compliance with the Belgian corporate governance code (Code Lippens)?

\section{Research Sample and Methodology}

\section{Sample}

The research sample has been constituted of the list of all 124 Belgian listed SMEs ${ }^{1}$ (status date: end of December 2006). This list of potential research subjects has been reduced with the elimination of Belgian Initial Public Offerings (IPOs) of the year 2006, as these companies did not fall within the scope of the Code Lippens in 2005 (the last available year for annual reports). However, some companies provide the necessary information (especially the annual report of 2005). As a result, they have been maintained in the population. Due to the IPO restriction, the effective population has been reduced to 101. Additionally, the companies of which the website did not exist or was not accessible in the period February-April 2007 have been excluded. This way, the population has been reduced to 86 companies. Additionally, the shares of three companies have been cancelled of Euronext at the beginning of 2007, due to a merger or an acquisition. As an effect, the annual accounts and corporate governance charter have been withdrawn from the corporate website. Additionally, 4 companies turned out not to be an SME and one company was in the process of liquidation.

These choices reduce the effective population to 78 listed Belgian SMEs. The entire population (100\%) has been investigated in this research, in order to be able to draw meaningful and relevant conclusions.

The specific category of companies addressed in this research - SMEs - is important for many European economies. Recent figures show that SMEs account for almost half of the GNP and more than $60 \%$ of total employment in Belgium. Therefore, they can be seen as cornerstone of Belgian economy. Other countries such as Finland and the Netherlands have similar figures. Especially in small open economies, SMEs usually play this role. Additionally, the adoption of the Code and its main effects can best be assessed within this SME framework. Indeed, larger companies usually tend to

1 The companies included in the sample concern companies with maximally 250 employees, publicly listed on a stock exchange and with registered office in Belgium. Bel-20 companies, the basket of Belgian reference shares, have been excluded of the research sample. 
comply at higher rate and faster pace, due to higher social visibility and larger resources. Recent research of the Federation of Enterprises in Belgium (2006) and the Belgian Governance Institute shows that BEL-20 companies on average comply with $87.9 \%$ of the Code's provisions after the first year of its introduction. As SMEs tend to have more work in adapting to the new guidelines and standards, this set of companies is key in analysing the real influence of the Code and the main obstacles. Following both arguments, SMEs have been chosen as main research subject to assess the influence of the Code on corporate governance practice in Belgium.

\section{Methodology}

The research data have been based on the companies' websites of February / March 2007, the last available version of their Corporate Governance Charters in February / March 2007 and the Annual Reports of 2005. This enables us to assess the compliance with the Code after its first year of introduction.

Not all the provisions of the Code (Corporate Governance Committee, 2004) have been included in this research, as it is impossible to assess each parameter based on the data available in annual reports, corporate governance codes and websites. Only these parameters have been included that could be investigated based on the publicly available information sources. Therefore, a selection has been made with the view to assuring the evaluation. The provisions that have been included in the research can be found in Appendix 1.

A case study approach in Belgium has been chosen instead of a broader international study. This idea has been inspired mainly by practical constraints. As the data-gathering and analysis process is timeconsuming, it would be unfeasible to perform the same in-depth analysis for more than one small(er) economy. The choice for investigation of one country allows performing the analyses with the entire population, thereby ensuring significant results and clear implications. It goes without saying that this single case study approach holds several limitations. Under these circumstances, it is impossible to provide a broader international comparison of governance practice after code introductions. Similarly, cultural differences on the compliance can not be studied, which could provide interesting knowledge. As a result, the conclusions and implications of this study should be considered exploratory and their scope and impact limited.

\section{Results}

This section will deal with the results of the study. In the first place, the most remarkable and eyecatching results will be discussed. The most important items of each section will be discussed in more detail.

The results (see Appendix 1 for detailed information) show that - on average - the listed Belgian SMEs included in the sample comply with $70 \%$ of the provisions as stipulated by the Belgian Code on Corporate Governance after the first year of its introduction (see Table 1 for more descriptive statistics). The 'comply or explain' principle is on average used in only $3 \%$ of the cases (equal to $10 \%$ of non-compliances). However, the disparity between different companies is large. The weakest student in class only complies with $7 \%$ of the provisions under investigation, while the best company complies with $98 \%$ of the provisions of the code and explains the other $2 \%$. Due to this largely dispersed landscape (for more detailed information, see the histogram in Figure 2), the results should be considered with cautiousness.

Table 1: Descriptive statistics.

\begin{tabular}{|l|l|}
\hline Mean $\%$ compliance & $70 \%$ \\
\hline Std. Dev. & $23 \%$ \\
\hline Min. \% compliance & $7 \%$ \\
\hline
\end{tabular}




\begin{tabular}{|l|l|}
\hline Max. \% compliance & $98 \%$ \\
\hline Min. \% compliance + explanation & $7 \%$ \\
\hline Max. \% compliance + explanation & $100 \%$ \\
\hline
\end{tabular}

Figure 2: Histogram.

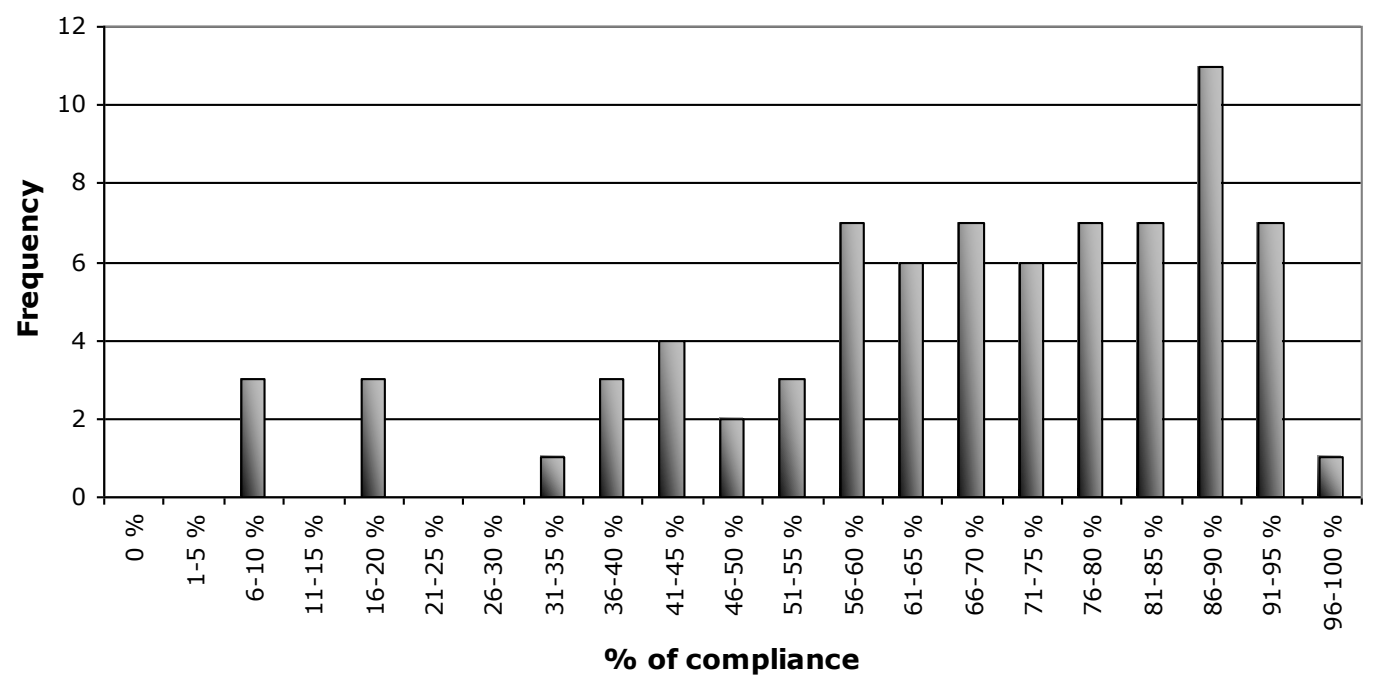

Interesting, remarkable and even a little frightening is the fact that only one company in our sample managed to have no provisions with non-compliance. This company made use of the explanation possibility for one provision. This observation can have two possible causes. In the first place, it is possible the incentives (socially, legally and financially) for companies to comply with the Code on Corporate Governance are insufficient, whereas the costs outweigh the benefits at this moment. Secondly, companies might more time to adapt their structures and operations to the new guidelines. After all, this study relies heavily on data of the first year of introduction of the Code.

\section{Provisions with high compliance}

The provisions with the highest rate of compliance all concern topics where no strategically important or 'private' information is disclosed and that firms used to disclose before the widespread attention to corporate governance. Mostly, the provisions complied with at high rate considers topics which have been disclosed in the annual reports previously to publication of the Code Lippens. Almost each company discloses the composition of its Board of Directors (97\%). In general, the recommendations related to the Board of Directors' composition are acted upon positively. Additionally, all but three companies $(96 \%)$ provide information on the relevant corporate governance events that took place during the year under review. The last provision with the highest compliance is the announcement of the timetable with periodic information and shareholders' meetings (96\%).

These first results actually do not contain any surprises or newly generated effects by the publication of the Code. Most listed companies have previously been disclosing this information in their annual reports.

\section{Provisions with high non-compliance}

In contrast to the previous items, where the provisions with the highest compliance included topics where no strategically important nor private information was to be disclosed, the provisions of the Code with the highest non-compliance concern more 'important' information. 
In the first place, $69 \%$ of the companies do not publish the main contractual terms of hiring and termination arrangements with executive managers. As with the results concerning low compliance (see section 5.3), this concerns more 'private' and individual information concerning team members. It seems that listed companies in general and SMEs in particular struggle with information disclosure on this kind of topics. A logical argument for this could be that they fear otherwise finding no suitable and competent Board and management members. Anyway, transparency in board transactions should not be over-ridden by considerations of directorial privacy. It is unacceptable that the privacy argument hampers overall transparency, which is one of the main aims of corporate governance codes.

Secondly, more than two-third of the companies $(67 \%)$ did not impose their non-executive directors not to consider taking on more than 5 directorships in listed companies. A reason for this low compliance rate could possibly be that companies are afraid of losing the best available directors by restricting their freedom. An alternative explanation relates to the interlocking directorates (Dooley, 1969; Schoorman et al., 1981), which are rather common in Continental Europe. In their research, Fich and White (2005) reported that about one company in seven was having interlocking directorates. The low compliance rate might be influenced by this common practice.

In third instance, the level of shareholding for the submission of proposals by a shareholder to the general shareholders' meeting, which should - according tot the Code - not exceed $5 \%$, is not complied with by $62 \%$ of the companies in our sample. In more than half of the cases, this level is higher (mostly $20 \%$ of shareholding). This higher level gives an indication of protection of larger shareholders (Berglöf and Pajuste, 2005; Claessens and Fan, 2002; Krivogorsky, 2006), thereby by-passing the objectives of the EU Action Plan, which aims at protecting all shareholders at equal level.

Additionally, companies are reluctant to disclose the results of the votes and the minutes of shareholders' meetings (59\% of the sample did not comply with this provision). In some way, it can be understood from a competitive point of view not to disclose the decisions being taken on a shareholders' meeting. On the other side, the most important decisions and strategies are being elaborated in the executive management and board meetings, without being disclosed to the outside world. Therefore, the non-compliance can be qualified as an obstruction to the goal of information disclosure, which has earlier been said to be very important for the functioning of markets.

Finally, the individual attendance of board members was not disclosed nor explained in almost half of the cases (54\%). The main reason can probably be found in the violation of the directors' privacy. Again, similar to the previous remark concerning the directorship in other listed companies, limiting the privacy and freedom of directors might be seen as a disadvantage in the search for good board members.

\section{Provisions with low compliance}

In contrast to the previous section, this section addresses the provisions of the Code with the lowest compliance. The difference is subtle but important, as low compliance does not necessarily mean noncompliance, especially in the context of the 'comply or explain' principle. Companies can decide not to comply, but have grounded arguments for deviation. However, low-compliance mostly reflects noncompliance without any explanation.

In the first place, the level of shareholding for the submission of proposals by a shareholder to the general shareholders' meeting returns in this section. As discussed in the previous section, this level should not exceed 5\%. However, the results reveal a small proportion of companies complying with this provision $(22 \%)$. The combination of these two elements (high non-compliance and low compliance) gives an indication that this provision really bothers companies. This indication should however be further investigated before any relevant inferential statements can be made.

A second interesting topic in this category concerns the frequency of audit committee meetings with the external and internal auditors. As prescribed by the Code, the committee should annually meet these auditors at least twice. However, only $26 \%$ of the sample elements comply with this guideline. In more than half of the cases, it is unclear whether these meetings take place or not. Generally, the annual 
reports provide little information on this subject, which explains the low compliance rate (as in only 21 $\%$ of the cases non-compliance can be registered with certainty).

Thirdly, less than one-third of the companies ( $28 \%$ ) did not impose their non-executive directors not to consider taking on more than 5 directorships in listed companies. Potential reasons have been discussed earlier. Again, the combination of two elements (high non-compliance and low compliance) gives an indication that this provision is not at all supported by listed Belgian SMEs and therefore requires more attention.

Finally - and again similar to the topic in the previous section, only $30 \%$ of the companies publishes the main contractual terms of hiring and termination arrangements with executive managers.

\section{Provisions with High Explanation for Non-Compliance}

The Code leaves a lot of freedom to companies by means of the 'comply or explain' principle. In case of non-compliance, the company can stipulate the reasons for the deviation, while still informing the public. Additionally, the principle offers the possibility of tailoring the general guidelines of the Code to the company's needs, which encourages and stimulates the general thought of corporate governance (Gillan, 2006; Marnet, 2007). As the results demonstrate, companies prefer not to disclose the reasons for non-compliance, thereby reducing the power of the 'comply or explain' principle and endangering the goal of information disclosure (Basu et al., 2007; Berglöf 1997; Berglöf and Pajuste, 2005; Claessens and Fan, 2002).

For some provisions however, the 'comply or explain' principle proves its use. Especially for the disclosure of CEO remuneration, the principle has found acceptance. In $13 \%$ of the cases, companies explain why the remuneration is not disclosed, while only $47 \%$ of the companies fully comply with the provision. Looking in more detail to this provision sheds another light on reality. Most explanations for non-compliance fence with protection of the CEO's privacy. They stipulate that disclosing the remuneration would bring damage to the privacy, which is an easy argument for non-compliance. The situation is even worse for detailed disclosure of the remuneration. The Code requires a split between basic and variable remuneration and other extra-legal components. The low compliance (42\%) is supplemented by a small amount (6\%) of explanations - again for reasons of privacy. This leaves $52 \%$ of the companies not complying or explaining deviation of the Code.

An important conclusion could be drawn out of this ascertainment. CEO remuneration, being an important tool to align the interests of shareholders /owners and management (Gillan, 2006), is being treated with high reluctance in the corporate governance framework. The good will of companies to align with the social and legal pressures towards more corporate governance might reach its limits when it concerns more personal items. Additionally, top managers might be afraid of downward pressure on their compensation packages in case of disclosure. This fear might be heightened by a study by Coombs and Gilley (2005), who found that a negative relationship exists for listed companies between the engagement in stakeholder management and CEO compensation. The authors concluded that "these results indicate that CEOs may jeopardize their personal wealth by pursuing stakeholder-related initiatives" (Coombs and Gilley, 2005, p.827). The same conclusion is found in another study by Basu et al. (2007). This suggests - in view of the actual discussion on the results of this study - that companies disclosing the remuneration package are more willing to pursue stakeholders' benefits and install good corporate governance mechanisms. In all cases, it should be stated that the individual privacy should not obstruct the primary goal of transparency.

The third provision with a high explanation rate for non-compliance envisages the level of shareholding for the submission of proposals by a shareholder to the general shareholders' meeting, which should according tot the Code - not exceed $5 \%$. In more than half of the cases, this level is higher, while only $10 \%$ of the companies provide an explanation. This higher level gives an indication of protection of larger shareholders (Berglöf and Pajuste, 2005; Claessens and Fan, 2002; Krivogorsky, 2006). 
A last provision giving a warm welcome to the 'comply or explain' principle relates to the constitution of advisory committees (audit, remuneration and nomination). These committees should be installed in order to support the Board with advice on specific matters, depending on their goal. As Siebens (2002) argued, the formation of specific committees can be helpful in case of specific knowledge or experience being required or in case of time consuming dossiers. Although generally companies effectively install and make use of these committees (respectively 76\%,76\% and 59\% for the audit, remuneration and nomination committee), non-compliance is generally explained (respectively in $13 \%, 15 \%$ and $17 \%$ of the cases). The main argument is that the size of the company - the sample only includes listed SMEs does not justify the installation of 3 additional committees, bringing additional costs and efforts.

\section{Special topics}

A first interesting topic concerns the Corporate Governance Charter. According to the Code, each listed Belgian company should constitute and publish a Corporate Governance Charter. In our sample 16 companies $(21 \%)$ have not met this requirement in early 2007, more than two years after the introduction of the Code. This indicates a potential discordant situation, where companies estimate that the cost of complying surpasses the benefits. As long as this situation holds, the (social and business) enforcement of the Code might become problematic (McWilliams and Siegel, 2001).

Another topic with remarkable results concerns the Board of Directors. In general, companies comply very well with the specifications concerning the Board of Directors. Not only do almost all companies disclose the composition of the Board, almost all of them meet the requirements concerning independence of at least 3 directors - as is common practice in the US (Krivogorsky, 2006) - and having half non-executives members (respectively $76 \%$ and $92 \%$ ). The last point is in contrast with the Japanese system, where the Board is being dominated by insiders (Basu et al., 2007). Additionally, as is called for by most corporate governance codes (Drew et al., 2006; Krivogorsky, 2006), most companies separate the role of CEO and chairman of the Board (82\%). These high compliance rates indicate that companies really put effort in getting their Board right.

The last topic with remarkable results is the part of the Code on remuneration in general. The disclosure of individual remuneration packages seems difficult to enforce via the Code. The only remuneration provision that receives sound compliance is the disclosure of executive managers' remuneration on a global basis. However, companies remain incredibly reluctant to disclose the individual remuneration packages of CEOs and non-executive directors. The situation becomes even worse in case of breakdown of the remuneration into basic remuneration, variable remuneration and other remuneration components. As quoted earlier in the article, privacy reasons lay the foundation for the low information disclosure, possibly combined with a fear for not being able to attract the best managers and directors. However, according to several studies, the relationship between disclosure of remuneration packages and the willingness to invest in corporate governance might be relevant in this context (Basu et al., 2007; Coombs and Gilley, 2005).

\section{Conclusions}

The institution of the Belgian Code on Corporate Governance at the end of 2004 in particular and codes on corporate governance in general can be seen as manifestations of the growing attention for corporate governance matters worldwide (Claessens and Fan, 2002). In Europe, the stimulating incentive has been generated by the European Commission with the main goal of disclosure of relevant and important company information, as stimulus for having well-functioning markets (Berglöf 1997; Berglöf and Pajuste, 2005; Claessens and Fan, 2002). This new élan has been identified as an interesting opportunity to evaluate the compliance of the targeted companies - listed Belgian SMEs - after the first year of the Code's introduction. This specific category of companies is important for many European economies. Recent research shows that SMEs account for almost half of the GNP and more than $60 \%$ of total employment in Belgium. Therefore, they can be seen as cornerstone of Belgian economy. Other countries such as Finland and the Netherlands have similar figures. 
In general, companies have embraced and adopted the Code rather well. The average compliance of the companies is rated at $70 \%$ after its first year of adoption. Large differences remain between the companies in the sample. Especially for smaller listed companies, the adaptation to the new set of guidelines and policy does not occur without striking a blow. Another interesting conclusion is that the 'comply or explain' principle has not become established yet. Non-compliance stays too often without any explanation. Time will tell whether this low level of explanation stems from unwillingness to disclose or from unfamiliarity with the principle.

However, some problematic areas remain. On a more abstract level, the identification of the provisions and topics with rather low compliance rates concern remuneration, private information on directors and inside information on shareholders' meetings. In first instance, the general level of disclosure of remuneration packages seems to experience substantial resistance from the companies, especially disclosure at individual and detailed level. This reluctance can be an important fact in view of different studies stressing the relationship between the disclosure of remuneration packages and the pursuit of stakeholders' interests (Basu et al., 2007; Coombs and Gilley, 2005). However, as this research focuses on data after the first year of introduction, this conclusion should not be dramatised. It is also possible that the reluctance to disclose the remuneration package is related to resistance to change, which will diminish in the course of time.

Secondly, the reluctance to disclose 'private' information concerning board members is significant. Too often, companies make a play with privacy statements to hide after. The hesitation to disclose this kind of information will probably erode over time - the corporate and societal culture needs an adaptation period. The fearfulness to disclose the individual-related information of board members can also be generated by the apprehension of not being able to attract some board members. As stated earlier, these obstacles will probably disappear in the course of time. The notion of directorial privacy should not override overall disclosure and transparency.

The third and last domain being subject to low compliance levels is the disclosure of 'inside' information, such as the results of the votes and the minutes of shareholders' meetings. Sometimes it is indeed preferable to keep aspects of these meetings behind closed doors. However, the most strategically important decisions are seldom taken on shareholders' meetings.

After the corporate scandals in the Western economies, a wave of corporate governance measures has been announced. The codes on corporate governance, recently introduced in many (European) countries are a manifestation of this 'hot topic'. As this study reveals, a long way remains to reach the goal of transparency and information disclosure, helping to assure good governance of companies. This should not discourage the many companies really working on the topic, as their results are rewarding. Obligatory reporting and regulation is in no way a guarantee to obtain genuine compliance with the code's principles and philosophy.

The generally encouraging image depicted in the previous sections should however be nuanced. More than one fifth of all listed Belgian SMEs does not comply with more than $50 \%$ of the provisions under investigation. This result provides a strong indication that companies estimate the benefits (mainly social, to a lesser extent financial) of complying lower than the costs associated with adoption. As long as this (perceived) negative cost balance holds, the adoption will remain problematic with a rather substantial proportion of companies. However, after the first year of introduction and considering the time companies sometimes need to adapt their policies, structures and procedures to the Code, it seems reasonable to give them the benefit of the doubt. Time will teach whether corporate governance has improved according to EU goals.

\section{Limitations of the study}

As discussed earlier, the chosen case study approach on Belgium holds several limitations. It is impossible to pronounce upon the influence of codes' introductions on corporate governance practice in a broader international context. Similarly, cultural differences on the compliance can not be studied. As 
a result, the conclusions and implications of this study should be considered exploratory and their scope and impact limited.

Secondly, the nature of the research design hampers in-depth analysis of real attitude changes in daily corporate governance practice. From this research, it is unclear whether the investigated companies really adapted their policies and actions and adopted the code. A gap might exist between what is reported and what actually happens in the field. Therefore, more in-depth qualitative research methodologies could complement the actual (exploratory) research.

A third important limitation of the study concerns the use of publicly available information. This kind of study only provides indications of to what extent companies live up to corporate governance recommendations. Reliance on publicly available information holds several risks. Companies might put a gloss on their real corporate governance practices in order to induce goodwill. Only a more in-depth study on day-to-day practices can provide further evidence on companies' real efforts to comply with corporate governance codes.

\section{Implications}

The results of the study potentially hold severe implications. Policy makers might have to reconsider the effectiveness of corporate governance codes as an attempt to foster good governance practices. As long as the costs to comply with governance codes outweigh the benefits - both financially and nonfinancially - the grounds for compliance will be lacking. The role of self-regulating codes has according to a long-term study in the United Kingdom by MacNeil and Li (2006) - been overstated. It seems that "investor's tolerance of non-compliance is linked to some extent with superior financial performance (in terms of share price" (MacNeil and Li, 2006, p. 494). Non-compliance is then not penalised in case of superior financial performance, while reasoned arguments for non-compliance remain unvalued (MacNeil and Li, 2006). In another study de Jong et al. (2004) indicated that little outcome can be expected from initiatives that rely on self-regulation and monitoring without any legal enforcement. The results of the study therefore plead for an integration of the corporate governance code into mainstream company law. Our results provide another indication - although preliminary and early in the Code's adoption process - for this statement.

\section{Further research opportunities}

Some research opportunities have been identified earlier in this article. In the first place, the study could be replicated in a broader international context, enabling more widely applicable conclusions. Intercultural comparison can reveal interesting differences in governance practices, taking different circumstances such as concentrated versus dispersed ownership into account. Additionally, research could address changes in daily practice after introduction of corporate governance codes with more indepth qualitative research methods to evaluate the gap between what companies report and what they actually do. Applying other approaches, such as participant observation and anonymous surveys, can substantially add to the understanding of obligatory reporting. Part of this study could relate to the question whether the Code should (partially) be integrated in company law. Thirdly, the scope of the research can be extended towards all listed companies, instead of focussing on SMEs, thereby analysing group differences between smaller and larger companies.

\section{Acknowledgements}

The author wishes to thank Prof. Dr. Marc Deloof (University of Antwerp, Belgium) and 2 anonymous reviewers for useful comments on earlier drafts of this paper. The author gratefully acknowledges financial support as PhD Fellow of the Research Foundation - Flanders (FWO Vlaanderen). 


\section{References}

Aaboen, L, Lindelöf, P, von Koch, C \& Löfsten, H 2006, 'Corporate Governance and performance of small high-tech firms in Sweden', Technovation, vol. 26, no. 8, pp. 955-968.

Aguilera, R \& Cuervo-Cazurra, A 2004, 'Codes of good governance worldwide: what is the trigger?', Organization studies, vol. 25, no. 3, pp. 415-443.

Anand, A 2005 'Voluntary vs. Mandatory Corporate Governance: Towards an Optimal Regulatory Framework', The Delaware Journal of Corporate Law, vol. 31, no. 1, pp. 229-252.

Basu, S, Hwang, L-S, Mitsudome, T \& Weintrop, J 2007, 'Corporate governance, top executive compensation and firm performance in Japan', Pacific-Basin Finance Journal, vol. 15, pp. 56-79.

Becht, M, Jenkinson, T \& Mayer, C 2005, 'Corporate governance: An assessment', Oxford Review of Economic Policy, vol. 21, no. 2, pp. 155-163.

Berglöf, E 1997, 'Boardrooms: Reforming corporate governance in Europe', Economic Policy, vol. 12, no. 24, pp. 91-123.

Berglöf, E \& Pajuste, A 2005, 'What do firms disclose and why? Enforcing corporate governance and transparency in Central and Eastern Europe', Oxford Review of Economic Policy, vol. 21, no. 2, pp. 178-197.

Claessens, S \& Fan, J P H 2002, 'Corporate Governance in Asia: A Survey', International Review of Finance, vol. 3, no. 2, pp. 71-103.

Coffee Jr, J C 2005, 'A theory of corporate scandals: Why the USA and Europe differ', Oxford Review of Economic Policy, vol. 21, no. 2, pp. 198-211.

Commission of the European Communities 2003, 'Modernising Company Law and Enhancing Corporate Governance in the European Union - A Plan to Move Forward', COM (2003), 284 final.

Coombs, J E \& Gilley, K M 2005, 'Stakeholder management as a predictor of CEO compensation: Main effects and interactions with financial performance', Strategic Management Journal, vol. 26, no. 9 , pp. 827-840.

Corporate Governance Committee 2004, The Belgian Code on Corporate Governance, viewed 25 October, 2007, <http://www.corporategovernancecommittee.be>.

Corporate Governance Committee 2007, Guidelines: Context and Objective, viewed 25 October, 2007, $<$ http://www.corporategovernancecommittee.be/en/committee/guidelines>.

Daily, C M, Dalton, D R \& Cannella Jr., A A 2003, 'Corporate Governance: decades of dialogue and data', Academy of Management Review, vol. 28, no. 3, pp. 371-382.

Dalton, C M \& Dalton, D R 2006a, 'Corporate governance best practices: the proof is the process', Journal of Business Strategy, vol. 27, no. 4, pp. 5-7.

Dalton, D R \& Dalton, C M 2006b, 'Spotlight on corporate governance', Business Horizons, vol. 49, pp. 91-95.

De Jong, A, DeJong, D V, Mertens, G \& Wasley, C E 2004, 'The Role of Self-Regulation in Corporate Governance: Evidence and Implications from The Netherlands' Simon School of Business Working Paper, No. FR 00-20; ERIM Report Series Reference No. ERS-2001-87-F\&A, viewed 25 October, 2007, <http://ssrn.com/abstract $=246952>$.

Dooley, P 1969, 'The interlocking directorate', American Economic Review, vol. 59, pp. 314-323.

Drew, S A, Kelley, P C \& Kendrick, T 2006, 'Five elements of corporate governance to manage strategic risk', Business Horizons, vol. 49, pp. 127-138.

Easterbrook, F \& Fischel, D 1996, The Economic Structure of Corporate Law, Harvard University Press, Cambridge, MA.

Federation of Enterprises in Belgium (FEB) 2006 'Naleving Code Lippens reeds na 1e boekjaar een success' Press Release $12^{\text {th }}$ July 2006, viewed 25 October, 2007, <http://www.vbofeb.be/index.html?file=2023>. (In Dutch)

Fich, E M \& White, L J 2005, 'Why do CEOs reciprocally sit on each other's boards?', Journal of Corporate Finance, vol. 11, pp. 175-195.

Frey, B S \& Benz, M 2005, 'Can private learn from public governance?', Economic Journal, vol. 115, no. 507, pp. F377-F396. 
Giannini, V 2001, 'How do outside directors add value to private companies? Q\&A with a California investment banker', Directorship, vol. 27, no. 10, pp. 8-12.

Gillan, S L \& Starks, L T 1998, 'A survey of shareholder activism: motivation and empirical evidence', Contemporary Finance Digest, vol. 2, no. 3, pp. 10-34.

Gillan, S L 2006, 'Recent developments in corporate governance: An overview', Journal of Corporate Finance, vol. 12, pp. 381-402.

Hendry, J 2005, 'Beyond Self-Interest: Agency Theory and the Board in a Satisficing World', British Journal of Management, vol. 16, pp. S55-S63.

Jensen, M C \& Meckling, W 1976, 'Theory of the firm: managerial behavior, agency costs, and capital structure', Journal of Financial Economics, vol. 3, pp. 305-360.

Krivogorsky, V 2006, 'Ownership, board structure, and performance in continental Europe', The International Journal of Accounting, vol. 41, pp. 176-197.

Levis, J 2006, 'Adoption of corporate social responsibility codes by multinational companies', Journal of Asian Economics, vol. 17, pp. 50-55.

Mallin, C 2001, 'Editorial, Corporate Governance and the Bottom Line', Corporate Governance, vol. 9, pp. 77-78.

Marnet, O 2007, 'History repeats itself: The failure of rational choice models in corporate governance', Critical Perspectives on Accounting, vol. 18, pp. 191-210.

MacNeil, I \& Xiao, L 2006, 'Comply or explain: market discipline and non-compliance with the combined code', Corporate Governance: An International Review, vol. 14, no. 5, pp. 486-496.

McWilliams, A \& Siegel, D 2001, 'Corporate Social Responsibility: A theory of the firm perspective', Academy of Management Review, vol. 26, no. 1, pp. 117-127.

Ooghe, H, Deloof, M \& Manigart, S 2002, Handboek bedrijfsfinanciering, Intersentia, Antwerp. (In Dutch)

Revilla, E, Sarkis, J \& Acosta, J 2005, 'Towards a knowledge management and learning taxonomy for research joint ventures', Technovation, vol. 25, pp. 1307-1316.

Schoorman, F, Bazerman, M \& Atkin, R 1981, 'Interlocking directorates: a strategy for reducing environmental uncertainty', Academy of Management Review, vol. 6, pp. 243-251.

Shleifer, A \& Vishny, R W 1997, 'A Survey of Corporate Governance', The Journal of Finance, vol. 52, no. 2, pp. 737-783.

Siebens, H 2002, 'Concepts and Working Instruments for Corporate Governance', Journal of Business Ethics, vol. 39, pp. 109-116.

Trott, P 1998, Innovation Management \& New Product Development, Prentice Hall, Harlow.

Van den Berghe, L A A \& Baelden, T 2005, 'The monitoring role of the board: one approach does not fit all', Corporate Governance, vol. 13, no. 5, pp. 680-690.

Vuola, O \& Hameri, A-P 2006, 'Mutually benefiting joint innovation process between industry and bigscience', Technovation, vol. 26, pp. 3-12.

Wieland, J 2005, 'Corporate Governance, values management and standards: a European perspective', Business \& Society, vol. 44, no. 1, pp. 74-93.

Wymeersch, E 2006, Corporate Governance Codes and Their Implementation, University of Ghent Financial Law Institute Working Paper No. 2006-10, viewed 25 October, 2007, $<$ http://ssrn.com/abstract $=931100>$. 